\title{
Transparansi Pengelolaan Dana Desa di Kecamatan Lemito \\ Kabupaten Pohuwato
}

\author{
Pebriyanto A. Hulinggi ${ }^{1)}$, Ismet Sulila ${ }^{2)}$, Rustam Tohopi ${ }^{3)}$ \\ Universitas Negeri Gorontalo ${ }^{1,2,3)}$ \\ febriyantohulinggi03@gmail.com,
}

\begin{abstract}
Abstrak
Artikel ini bertujuan untuk mengetahui bentuk transparansi pengelolaan Dana desa di Kecamatan Lemito Kabupaten Pohuwato. Dengan mengunakan metode pendekatan kualitatif. Teknik pengumpulan data yang dilakukan dalam penelitian ini yaitu dengan melakukan wawancara pada informan yang terdiri dari Sekretaris Dinas PMD Kabupaten Pohuwato, Camat Lemito, Tim Satgas, Kepala Desa dan masyarakat. Hasil penelitian menunjukan bahwa pemerintah Desa diKecamatan Lemito sudah melakukan bentuk transparansi dalam mengelolah Dana desa yang diperuntukan pada pembangunan dan pemberdayaan masyarakat desa, berdasarkan hasil penelitian dilapangan menunjukan bahwa pemerintah desa di Kecamatan Lemito belum sepenuhnya transparansi dimana masyarakat masih sulit mengakses informasi terkait dengan penggunaan Dana desa yang dikelolah oleh pemerintah Desa.
\end{abstract}

\section{Kata Kunci: Dana Desa; Transparansi}

\begin{abstract}
This article aims to determine the form of transparency in the management of village funds in Lemito District, Pohuwato Regency. By using a qualitative approach method. The data collection technique used in this study was to conduct interviews with informants consisting of the Secretary of the Pohuwato Regency PMD Office, Lemito Sub-District Head, the Task Force Team, the Village Head and the community. The results showed that the Village government in Lemito Subdistrict has implemented a form of transparency in managing village funds that are intended for development and empowerment of village communities, based on the results of field research shows that the village government in Lemito District is not fully transparent where the community is still difficult to access information related to the use of village funds. Managed by the Village government.
\end{abstract}

Keywords: Village Funds; Transparency 


\section{Pendahuluan}

Desa merupakan suatu kelompok masyarakat hukum yang terdapat batas wilayah yang memiliki hak untuk mengelolah masalah pemerintahan demi kepentingan masyarakat publik dan juga adanya tanggungjawab besar dalam mengelolah keuangan desa. Pemerintah desa diwajibkan melakukan Transparansi pengelolaan keuangan desa dalalm hal ini Dana desa yang bersumber dari APBN, hal demikian merupakan bagian terpenting didalam pengelolaan Dana desa sejak adanya peraturan UU Nomor 6 Tahun 2014 tentang desa, dimana setiap desa telah dipercayakan oleh pemerintah pusat dan juga masyarakat dalam mengelolah anggaran yang relative besar nilainya.

Harapan besar bahwa anggaran desa dikelolah secara transparan baik dari tahapan perencanaan sampai pada tahapan pelaksanaan bahkan sampai pada evaluasi pelaksanaan kegiatan desa.APBDes merupakan instrument pengelolaan keuangan yang penting bagi desa itu sendiri sebagaimana pada pasal 2 Permendagri 113 tahun 2014 menyatakan bahwa keuangan dikelolah berdasarkan asas transparansi, akuntabel, partisipatif serta tertib dan disiplin anggaran. Transparansi merupakan hal penting bagi organisasi pemerintahan terutama dalam pengelolaan dana desa, sebagaimana yang dikemukakan oleh Atmadja, dkk 2013 (yang dikutip oleh Ayumiati dan Ferdinand, 2019: 62) bahwa Transparasni merupkan organisasi yang menyediakan informasi secara terbuka yang menyangkut informasi yang relevan serta mudah di akses dan dipahami oleh pemangku kepentingan.

Transparansi adalah keterbukaan pemerintah dalam memberikan informasi yang terkait dengan ativitas pengelolaan sumber daya publik kepada pihak yang membutuhkan yaitu masyarakat (Mardiasmo, 2006) dalam (Julita \& Abdullah, 2020:214). Jelasnya ketika masyarakat sudah ikut aktif dalam pengelolaan Dana desa maka pemerintah desa sudah transparansi.

Sama halnya yang terjadi di Kecamatan Lemito Kabupaten Pohuwatobahwasanya masih ada beberapa Desa yang masih belum maksimal melakukan bentuk transparansi secara terbuka kepada publik dalam hal ini kepada masyarakat.

Kecamatan Lemito Kabupaten Pohuwato terdiri dari delapan Desa yang memperoleh Dana desa sebagai berikut:

Tabel 1. Jumlah Dana Desa Di Kecamatan Lemito

\begin{tabular}{|c|c|c|c|c|c|c|c|}
\hline \multirow[b]{2}{*}{ No. } & \multirow[b]{2}{*}{ Desa } & \multicolumn{2}{|c|}{2017} & \multicolumn{2}{|c|}{2018} & \multicolumn{2}{|c|}{2019} \\
\hline & & $\begin{array}{c}\text { Jumlah } \\
\text { (Rp) }\end{array}$ & $\begin{array}{c}\text { Realisasi } \\
\text { (Rp) }\end{array}$ & $\begin{array}{c}\text { Jumlah } \\
\text { (Rp) }\end{array}$ & $\begin{array}{c}\text { Realisasi } \\
\text { (Rp) }\end{array}$ & $\begin{array}{c}\text { Jumlah } \\
\text { (Rp) }\end{array}$ & $\begin{array}{c}\text { Realisasi } \\
\text { (Rp) }\end{array}$ \\
\hline 1 & Babalonge & 664.765 .500 & 620.905 .500 & 802.256 .754 & 762.070 .662 & 770.488 .052 & 770.488 .052 \\
\hline 2 & Lomuli & 812.204 .159 & 745.004 .159 & 769.531 .559 & 521.650 .575 & 872.926 .055 & 872.926 .055 \\
\hline 3 & Kenari & 710.845 .326 & 676.245 .326 & 741.094 .830 & 445.226 .450 & 831.967 .000 & 831.967 .000 \\
\hline 4 & Lemito Utara & 794.218 .158 & 746.718 .158 & 924.722 .500 & 924.722 .500 & 722.270 .230 & 722.270 .230 \\
\hline 5 & Lemito Induk & 839.022 .834 & 827.253 .964 & 773.129 .784 & 773.129 .784 & 745.724 .702 & 745.724 .702 \\
\hline 6 & Woggarasi Barat & 810.603 .644 & 667.500 .000 & 1.02 .3636 .000 & 1.023 .636 .000 & 683.416 .337 & 683.416 .337 \\
\hline 7 & $\begin{array}{l}\text { Woggarasi } \\
\text { Tengah }\end{array}$ & 7630.46 .412 & 749.216 .500 & 952.801 .912 & 952.801 .912 & 1.159 .515 .789 & 1.159 .515 .789 \\
\hline
\end{tabular}




\begin{tabular}{rrrrrrrr}
\hline 8 & Suka Damai & 789.987 .207 & 709.987 .207 & 679.164 .207 & 678.767 .257 & 612.646 .000 & 612.646 .000 \\
\hline & Total $($ Rp) & $\mathbf{6 . 1 8 4 . 6 9 3 . 2 4 0}$ & $\mathbf{5 . 7 4 2 . 8 3 0 . 8 1 4}$ & $\mathbf{6 . 6 6 6 . 3 3 7 . 5 4 6}$ & $\mathbf{6 . 0 8 2 . 0 0 5 . 1 4 0}$ & $\mathbf{6 . 3 9 8 . 9 5 4 . 1 6 5}$ & $\mathbf{6 . 3 9 8 . 9 5 4 . 1 6 5}$ \\
& & &
\end{tabular}

Sumber Data: Kecamatan Lemito, 2019

Pemerintah desa saat ini masih belum berfungsi secara maksimal, dimana masih ada masyarakat desa yang sulit memperoleh informasi terkait dengan penggunaan anggaran Dana desa, ditambah dengan para penerimah bantuan yang bersumber dari Dana desa tidak menerimah rincian anggaran bantuan, diantaranya anggaran pembelian sapi ternak dan rincian anggaran bantuan rumah rehap.

Berikut pengelolaan Dana desa dalam bidang pembangunan dan desa di Kecamatan Lemito Kabupaten

Pohuwato:

Tabel 2. Pengelolaan Anggaran Dana Desa Pada Bidang Pembangunan Desa Kecamatan Lemito

\begin{tabular}{ccc}
\hline $\begin{array}{c}\text { Tahun } \\
\text { Anggaran }\end{array}$ & Penganggaran & Realisasi \\
\hline 2017 & 2.342 .641 .950 & 2.341 .857 .384 \\
2018 & 4.080 .171 .782 & 3.762 .509 .162 \\
2019 & 4.664 .198 .850 & 4.664 .198 .850 \\
\hline Jumlah & $\mathbf{6 4 2 2 8 1 3 7 3 2}$ & $\mathbf{1 0 7 6 8 5 6 5 3 9 6}$
\end{tabular}

Sumber Data: Kecamatan Lemito Tahun 2019

Bentuk pengelolaan Dana desa di kecamatan lemito pada tahun 2017 penganggaran pembangunan desa Rp. 2.342.641.950 dan realisasi mencapai Rp. 2.341.857.384, berikut pada tahun 2018 jumlah anggaran yang diperoleh dengan nilai Rp. 4.080.171.782 dan direalisasikan berkisar Rp. 3.762.509.162, dan tahun 2019 jumlah anggaran Rp. 4.664.198.850 di realisasi mencapai target penganggaran.

Adanya anggaran yang bersumber dari APBN yang tujuannya untuk pembangunan infrastruktur desa, maka dengan jumlah anggaran yang ada perlu untuk melakukan transparansi pemerintah desa kepada masyarakat, terutama upaya yang harus dilakukan yaitu melibatkan masyarakat desa pada setiap program yang dicanangkan. Adapun bentuk laporan penggunaan anggaran Dana desa perlu disampaikan kepada masyarakat melalui rapat desa atau memanfaatkan media sehingga masyarakat mudah untuk mengakses informasi penyelesaian kegiatan desa. Dana desa tidak hanya fokus pada pembangunan infrastruktur, akan tetapi juga lebih kepada pemberdayaan masyarakat yang anggarannya juga sudah ada. Berikut anggaran Dana desa yang dikelolah oleh pemerintah desa pada tiga tahun terakhir pada pemberdayaan masyarakat di Kecamatan lemito: 
Tabel 3. Pengelolaan Anggaran Dana Desa

Pada Pemberdayaan Masyarakat Kecamatan Lemito

\begin{tabular}{lll}
\hline Tahun Anggaran & Penganggaran & Realisasi \\
\hline 2017 & 3.842 .051 .290 & 3.400 .973 .430 \\
2018 & 2.586 .165 .764 & 2.319 .495 .978 \\
2019 & 1.734 .755 .315 & 1.734 .755 .315 \\
\hline \hline
\end{tabular}

Sumber Data: Kecamatan Lemito Tahun 2019

Dalam bidang pemberdayaan masyarakat desa di Kecamatan Lemito pada tahun 2017 anggaran pemberdayaan senilai Rp. 3.842.051.290 dan realisasi mencapai Rp. 3.400.973.430, pada tahun 2018 jumlah anggaran pemeberdayaan berjumlah Rp. 2.586.165.764 dan bentuk realisasi mencapai Rp. 2.319.495.978, berikut tahun 2019 jumlah anggaran pada bidang pemeberdayaan berjumlah Rp. 1.734.755.315. Berdasarkan data yang diperoleh dalam pembangunan dan pemberdayaan desa yang ada di Kecamatan Lemito menunjukan bahwa pengelolaan Dana desa perlu diketahui oleh masyarakat umum sehingga bentuk transparansi dalam pengelolaan Dana desa lebih baik lagi.

Sebagaiamana hasil penelitian yang dilakukan oleh Julita, E., \& Abdullah, S. (2020) dengan judul Transparansi Dalam Pengelolaan Dana Desa (studi di Kecamatan Sukakarya Kota sabang) bahwa transparansi dalam pengelolaan Dana desa perlu adanya:

1) Pemahaman aparatur desa terkait dengan transparansi pengelolaan Dana desa,

2) Persepsi masyarakat terkait transparansi dalam pengelolaan Dana desa secara umum,

3) Partisipasi masyarakat dalam proses perencanaan dan pelaksanaan pengelolaan Dana desa.
Berikut hasil penelitian yang dikemukakan oleh Ayumiati, dkk (2019) dengan judul Transparansi Pengelolaan Dana Desa di Kabupaten Bireaun, dimana hasil penelitian menujukan bahwa pengelolaan Dana gampong di Kabupaten Bireaun sudah berjalan secara transparan baik dari proses keterbukaan, proses perencanaan, penyusunan dan pelaksanaan anggaran Dana desa. Begitu halnya dengan kesediaan dan aksebilitas dokumen, kejelasan dan kelengkapan informasi, keterbukaan proses dan kerangka regulasi yang menjamin transparansi.

Dari hasil penelitian yang ada maka hal demikian perlu menjadi rujukan pemerinatah desa di Kecamatan Lemito dikarenakan bentuk transparansi pengelolaan Dana desa yang belum maksimal dilakukan oleh pemerintah desa, dimana masih adanya masyarakat yang belum mengetahui keseluruhan anggaran yang digunakan dalam pembangunan dan pemberdayaan begitupun dengan sulitnya masyarakat memperoleh informasi, sehingga sangat menarik untuk diteliti secara akademik dan bisa memberikan gambaran secara umum terkait dengan bentuk pengelolaan Dana desa secara transparan yang dilakukan oleh pemerintah desa guna untuk kesejahteraan masyarakat desa di Kecamatan Lemito kabupaten Pohuwato. 


\section{Kajian Teori}

\section{Pengertian APBDes}

Secara struktur APBDes menurut Peraturan Menteri Dalam Negeri Nomor 113 Tahun 2014 tentang pengelolaan keuangan desa, dimana pada pasal 8 ayat 1 APBDes terdiri dari atas:

1) Pendapatan Desa. Pada pasal 9 ayat (1) sudah jelas bahwa pendapatan desa meliputi semua penerimaan uang melalui rekening desa yang merupakan hak desa dalam 1 tahun anggaran yang tidak dibayar kembali oleh desa. Pendapatan desa bersumber dari PADesa (Pendapatan Asli Desa), transfer dan lain-lain.

2) Belanja desa. Belanja desa meliputi semua pengeluaran dari rekening desa yang merupakan kewajiban desa dalam 1 tahun anggaran yang tidak akan diperoleh pembayarannya kembali oleh desa. Belanja pada pemerintah desa meliputi biaya belanja pegawai, belanja barang dan jasa, dan belanja modal.

3) Pembiayaan desa. Pembiayaan desa merupakan penerimaan yang perlu dibayar kembali dan/atau pengeluaran yang akan diterima kembali, baik pada tahun anggaran yang bersangkutan maupun pada tahun-tahun anggaran berikutnya. Pembiayan desa terdiri atas penerimaan pembiayaan yang mencakup: a). SilPA (sisa lebih perhitungan anggaran) tahun sebelumnya, b). Pencairan Dana cadangan, dan c). Hasil penjualan kekayaan desa yang dipisahkan. Berikut pembiayaan desa terdiri dari pengeluaran yang mencakup: a). pembentukan Dana cadangan, b). penyertaan modal desa.

\section{Kebijakan Dana Desa}

Menurut Ramdhani, \& Ramdhani (2017)

dalam Sunardi, N., \& Lesmana, R. (2020) "menyatakan bahwa pelaksanaan kebijakan adalah penerapan suatu peraturan program, aksi dan tindakan serta tindakan dalam suatu aturan yang menyatu pada suatu sistem tertentu.

Berdasarkan Undang-undang nomor 6 tahun 2014 tentang desa, Keuangan Desa adalah semua hak dan kewajiban Desa yang dapat dinilai dengan uang serta segala sesuatu berupa uang dan barang yang berhubungan dengan pelaksanaan hak dan kewajiban Desa. Adapun yang berhubungan dengan kebijakan pengelolaan keuangan desa sudah diatur dalam Peraturan pemerintah nomor 8 tahun 2016 tentang dana desa, dimana Dana desa bersumber dari APBN (Anggaran Pendapatan Belanja Negara) yang pengelolaanya sudah diatur dalam Permendagri nomor 113 tahun 2014 tentang pengelolaan keuangan desa. Berdasarkan kebijakan yang ada sudah jelas bahwa pengelolaan keuangan khususnya pengelolaan keuangan desa sudah diatur sehingga tujuannya untuk pengelolaan Dana desa yang tepat sasaran.

Adapun kebijakan pengelolaan dana desa di Kabupaten Pohuwato sudah diatur dalam Peraturan Bupati Pohuwato nomor 46 tahun 2015 tentang pengelolaan keuangan desa, dimana Dana Desa merupakan dana yang bersumber dari anggaran pendapatan dan belanja negara yang diperuntukan bagi Desa yang ditransfer melalui anggaran pendapatan dan belanja daerah Kabupaten Pohuwato dan digunakan untuk membiayai penyelenggaraan pemerintahan, pelaksanaan pembangunan, pembinaan kemasyarakatan, dan pemberdayaan masyarakat. Maka sudah jelas bahwa 
anggaran yang bersumber dari APBN tersebut harus dipertanggungjawabkan oleh pemerintah desa dan juga pengelolaan Dana desa harus transparan kepada masyarakat itu sendiri. Jelas pasal 3 ayat 2 menjelaskan bahwa Asas transparan sebagaimana dimaksud pada ayat (1) merupakan prinsip keterbukaan yang memungkinkan masyarakat untuk mengetahui dan mendapatkan akses informasi seluas-Iuasnya tentang keuangan desa.

\section{Pelaksanaan Pengelolaan Dana Desa}

Pengelolaan Dana desa menurut Thomas (2013) dalam Sunardi, N., \& Lesmana, R. (2020) adalah suatu proses atau suatu rangkaian pekerjaan yang dilakukan oleh serangkaian kelompok orang di dalamnya terdapat perencanaan, pengorganisasian, pelaksanaan dan pengawasan dengan memanfaatkan potensi yang ada dalam mencapai tujuan tertentu. Dana desa juga sudah diatur dalam Peraturan Pemerintah nomor 8 tahun 2016 dana desa yang bersumber dari Anggaran Pendapatan Belanja Negara (APBN) guna untuk pembiayaan penyelenggaraan pemerintahan baik dari segi pembangunan serta pemberdayaan masyarakat dan pembinaan masyarakat. Tujuan pemberian Dana desa disesuikan dengan kebutuhan masing-masing desa.

Pelaksanaan pengelolaan dana desa dimana adanya tindakan yang dilakukan oleh individu maupun kelompok baik pemerintahan maupun swasta yang diarahkan pada pencapaian tujuan maupun sasaran sebagaiamana yang dikemukakan oleh Yudianto Noverman (2018) dalam Sunardi, N., \& Lesmana, R. (2020) menyatakan bahwa pelaksanaan pengeloaan Dana Desa adalah tindakan-tindakan yang dilakaukan oleh individuindividu (dan kelompok) pemerintah dan swasta yang diarahkan pada pencapaian tujuan dan sasaran yang telah ditetapkan dari pengertian diatas dapat disimpulkan implementasi kebijakan terdiri dari tiga hal, yaitu (1) tujuan atau sasaran kebijakan, (2) aktivitas atau kegiatan pencapaian tujuan, dan (3) hasil kegiatan. Adapun empat variabel terkait dengan keberhasil suatu kebijakan menurut Edwards III (1980) yaitu (1) komunikasi, (2) sumber daya (3) disposisi, dan (4) struktur birokrasi.

Jelasnya sudah diatur dalam Peraturan Presiden Nomor 43 pasal 93 Tahun 2014 Pengelolaan Keuangan Desa adalah semua kegiatan yang meliputi (1) Perencanaa, (2) Penganggaran,
(3)
Penatausahaan,
(4) Pelaporan,

pertanggungjawaban, dan (6) pengawasan keuangan desa. Sehingga dapat disimpulkan bahwa dalam pengelolaan Dana desa dilakukan perencanaan dalam pelaksaan kegiatan yang menggunakan Dana desa, sehingga sampai pada tahapan pertanggungjawaban dan pengawasan anggaran.

\section{Transparansi Dana Desa}

Bentuk transparansi dimaksud seperti yang dikemukakan oleh Talengkera, dkk (2018) dalam Setyawati \& Ferdinand (2020) transparansi dapat dirinci menjadi beberapa indikator, antara lain:

1. Penyediaan dan akses informasi yang jelas tentang perencanaan, prosedur pelaksanaan dan pertanggung jawaban.

2. Adanya musyawarah yang melibatkan masyarakat.

3. Keterbukaan proses pengelolaan.

4. Keterbukaan informasi tentang dokumen pengelolaan Dana desa.

Jelas bahwa indikator transparansi pengelolaan

Dana desa intinya pemerintah desa perlu melakukan 
penyampaian informasi kepada masyarakat, memudahkan masyarakat mengakses informasi sudah masuk pada bentuk peningkatan transparansi. Adapun pendapat lain yang dikemukakan oleh Mahmudi (2016) dalam Amalia \& Mahsuni (2020) transparansi adalah keterbukaan dalam sebuah organisasi untuk memberikan informasi secara nyata yang berkaitan dengan aktivitas pengelolaan terhadap sumber daya publik kepada pihak yang membutuhkan dan menjadi pemangku juga pengelola kepentingan.

Kedua teori yang ada sudah jelas bahwa transparansi Dana desa merupakan bentuk tanggungjawab yang paling utama dilakukan oleh pemerintah desa dari tahapan perencanaan, pelaksanaan sampai pada tahapan evaluasi. Sehingga akan berakibat pada pencapaian tujuan kebijakan yang sudah ditetapkan terkait dengan pengelolaan anggaran desa dalam hal ini lebih kepada Dana desa.

\section{Metode Penelitian}

Jenis penelitian ini menggunakan deskriptif kualitatif, dengan melakukan wawancara secara mendalam (in-depth interviews) kepada informan penelitian. Penggunaan metode yang ada digunakan sesuai dengan tujuan penelitian. Penelitian ini dilakukan selama 6 (enam) dari bulan Desember 2019 sampai dengan Mei 2020. Subjek penelitian ini untuk mengetahui penerapan kebijakan pengelolaan Dana desa dalam transparansi kepada masyarakat secara terbuka. Informan dalam penelitian ini terdiri dari Camat, Kepala Desa, BPD, dan tokoh masyarakat Kecamatan lemito. Adapun teknik pengumpulan data yaitu melalui observasi partisipatif, wawancara mendalam, dan dokumentasi.

\section{Hasil dan Pembahasan}

\section{Hasil Penelitian}

Undang-undang nomor 6 tahun 2014 tentang desa, sudah jelas bahwa desa diberikan wewenang untuk melaksanakan pemerintahannya sendiri dalam bentuk kegiatan pelaksanaan pembangunan dan pemberdayaan guna untuk kesejahteraan masyarakat dan meningkatkan hidup masyarakat yang memiliki kualitas yang baik. Sehingga, pemerintah desa diharapkan dapat menerapkan prinsip diantaranya bentuk transparansi dalam melakukan pengelolaan Dana desa sehingga dapat mencapai tujuan daripada Dana desa yang diperuntukan bagi masyarakat desa yang menjadi tanggungjawab pemerintah desa baik secara fisik maupun non fisik.

Transparansi Dana desa yang dilaksanakan oleh pemerintah desa berdasarkan asas kebijakan yang sudah ditetapkan. Dinas PMD Kabupaten Pohuwato, lebih menekankan pada penguatan pada hal teknik, seperti transpanransi anggaran kepada publik melalui pemasangan Baliho yang memuat informasi program dan alokasi anggaran yang dibutuhkan.

Selanjutnya pihak pemerintah kecamatan Lemito, meneruskan dan melaksnakan informasi kebijakan transparansi pengelolaan dana ini sudah merencanakan sesuai dengan anggaran yang ada kemudian dampaknya untuk kesejahteraan rakyat/ masyarakat. Dari sistem perencanaan Dana desa, dari musyawarah dusun, musyawarah desa, sampai masuk perencanaan penganggaran dan sebagainya, ada tahapan tahapan itu. Jadi sudah jelas, penggunaan Dana desa. Transparansi yang ada 
sekarang sudah menggunakan sistem non tunai sehingga bendahara desa tidak lagi menerima anggaran desa, dikarenakan sistem keuangan sudah langsung ditransfer dari kas Negara untuk Dana desa kepada misalnya salah satu tokoh bangunanyang ditunjuk oleh pemerintah desa dalam pengadaan bahan bangunan.

Selanjutnya Tim Satgas Kecamatan dan Tim satgas Dana desa dibentuk langsung oleh Dinas PMD Kabupaten Pohuwato terkait transparansi yang dilakukan oleh pemerintah desa kepada masyarakat terkait dengan pengelolaan Dana desa, peran dari Tim satgas yakni melakukan verifikasi berkas APBDes dan RKPDes yang dimasukan oleh Pemerintah Desa, Transparansi harsunya memasang baliho terkait dengan rincian anggaran dan juga desain pembangunan Kantor desa.

Pengelolaan dana desa pada level pemerintah desa menindaklanjuti bentuk transparansi pengelolaa desa dengan tahapan yakni: melalui proses perencanaan program yang dimulai dari Musdus, Musdes, Musrenbang. Setiap semua melibatkan masyarakat. Maka sudah bisa disimpulkan apapun yang diputuskan kegiatannya baik anggarannya itu adalah hasil putusan dari forum musyawarah desa yang berikut akses lainnya yang dilakukan oleh pemerintah desa untuk mewujudkan transparansi adalah disamping pengambilan putusan darisemua kegiatan baik penggunaan anggarannya itu adalah lewat dari bahan informasi contohnya desa diwajibkan dalam bentuk baliho.

Berdasarkan hasil penelitian ini dalam hal ini Dinas PMD Kabupaten Pohuwato, Camat Lemito, Tim Satgas Dana Desa, dan Kepala Desa, dapat disimpulkan bahwa bentuk transparansi yang dilakukan oleh pemerintah desa yang ada di Kecamatan Lemito terkait dengan pengelolaan Dana desa belum sepenuhnya maksimal, dimana transparansi Dana desa hanya sebatas penyampaian pada saat musyawarah desa dan pemberian informasi melalui baliho, akan tetapi pada pelaporan penggunaan anggaran desa tidak dipublish kepada masyarakat desa, hal demikian mengakibatkan masyarakat kesulitan untuk memperoleh informasi yang berhubungan dengan penggunaan anggaran desa.

\section{Pembahasan}

Desa merupakan pemerintahan terkecil yang memiliki wewnang untuk mengatur rumah tangganya sendiri dengan tujuan untuk mencapai kemandirian sebagaimana yang Septian (2016) dalam Moh, F. (2019) berpendapat bahwa dalam mengoperasikan desa untuk mewujudkan kemandirian yang diberikan kepada desa terdapat pembiayaan-pembiayaan, yang memiliki ikatan dengan Dana desa, sehinggan Pemda kabupaten menyalurkan Dana desa keseluruh desa yang berada diteritorialnya. Pengelolaan Dana desa yang ada di Kecamatan lemito merupakan Dana yang digunakan untuk pembangunan dan pemberdayaan masyarakat, hal demikian sudah baik dilakukan oleh pemerintah dilihat dari berbagai macam program desa yang sudah dicanangkan. Akan tetapi masih ada adanya bentuk transparansi yang dilakukan oleh pemerintah yang kurang melibatkan masyarakat desa. Bentuk transparansi yang dilakukan oleh pemerintah desa hanya sebatas penyampaian pada saat diadakan rapat desa atau musyawarah desa dan dilakukannya pemasangan baliho hanya terkait dengan total anggaran. Masih 
adanya masyarakat yang sulit memperoleh informasi penggunaan anggaran desa.

Adapun bentuk transparansi sesuai amanah undang-undang sebagaimana pada pasal 2 Permendagri 113 tahun 2014 menyatakan bahwa keuangan dikelolah berdasarkan asas transparansi, akuntabel, partisipatif serta tertib dan disiplin anggaran dan diperjelas lagi pada peraturan Bupati Pohuwato nomor 46 tahun 2015 pasal 3 ayat 2 menjelaskan bahwa Asas transparan sebagaimana dimaksud pada ayat (1) merupakan prinsip keterbukaan yang memungkinkan masyarakat untuk mengetahui dan mendapatkan akses informasi seluas-Iuasnya tentang keuangan desa.Jelas peraturan yang ada akan tetapi pemerintah desa di kecamatan lemito belum sepenuhnya melakukan hal-hal demikan. Kesimpulannya bentuk pengelolaan Dana desa di Kecamatan Lemito belum sesuai dengan harapan peraturan ataupun undangundang yang sudah dicanangkan yang mengatur tentang pengelolaan Dana desa khususnya pada bagian transparansi penggunaan Dana desa.

Keberhasilan transparansi pengelolaan Dana desa dapat kita lihat pada pencapaian pemerintah desa dalam meyakinkan dana kepercayaan masyarakat desa, adanya bentuk kerjasama masyarakat dan pemerintah desa dalam memanfaatkan anggaran desa dalam pembangunan dan pemberdayaan sebagaimana transparansi menurut (Hamid, 2007)dalam Nangsih dan Eriyanti (2019) bahwa keberhasilan transparansi dapat dilihat dari beberapa indikator diantaranya yaitu : a). Meningkatnya keyakinan dan kepercayaan publik kepada institusi bahwa institusi adalah bersih dan berwibawa, b). Meningkatnya partisipasi publik dalam penyelenggaraan institusi, c). Bertambahnya wawasan dan pengetahuan publik terhadap penyelenggaraan institusi, d). Berkurangnya pelanggaran terhadap peraturan perundangundangan yang berlaku.

Berdasarkan realita yang terjadi di beberapa desa yang ada di Kecamatan lemito bentuk transparansi dalam pengelolaan ataupun penggunaan anggaran Dana desa belum mencapai keberhasilan, dimana masih adanya kurang kepercayaan ataupun keyakinan masyarakat kepada pemerintah desa untuk mengelolah anggaran Dana desa, apalagi berbicara pengetahuan publik terkait dengan penggunaan anggaran desa dimana masyarakat sulit memperoleh pertanggungjawaban pemerintah desa dan bentuk partisipasi hanya nampak pada masyarakat yang memperoleh bantuan sehingga permasalahan yang ada berdampak pada kebijakan Daerah yang sudah dicanangkan.

\section{Kesimpulan dan Saran}

\section{Kesimpulan}

Berdasarkan hasil penelitian dilapangan bahwasanya pengelolaan Dana desa yang dilakukan oleh pemerintah desa di Kecamatan Lemito yang terdiri dari delapan desa, masih adanya desa yang belum melakukan trasparansi pengelolaan Dana desa secara meluas kepada masyarakat desa pada umumnya. Bentuk transparansi yang dilakukan sesuai penyampaian oleh beberapa informan, dimana pemerintah desa dalam hal ini kepala desa hanya menyampaikan pada saat diadakan rapat desa atau hanya penyampaian melalui baliho yang menyangkut total anggaran. Pemerintah desa belum sepenuhnya mengikuti apa yang menjadi harapan undang-undang ataupun peraturan Daerah terkait 
pengelolaan Dana desa, dimana Dana desa dilakukan secara transparan dan memudahkan masyarakat memperoleh akses terkait dengan penggunaan anggaran.

\section{Saran}

Sebaiknya pemerintah desa memanfaatkan adanya media sosial untuk melakukan transparansi pengelolaan Dana desa secara administrasi, agar masyarakat bisa memperoleh bentuk laporan secara administrasi oleh pemerintah desa dalam hal ini kepala desa terkait dengan penggunaan anggaran khususnya Dana desa yang bersumber dari APBN.

\section{Referensi}

Ayumiati, A., Isnaliana, I., \& Jalilah, J. (2019). Transparansi Pengelolaan Dana Desa di Kabupaten Bireun. Jurnal EMT KITA, 3(2), 61-69.

Julita, E., \& Abdullah, S. (2020). Transparansi Dalam Pengelolaan Dana Desa (Studi Di Kecamatan Sukakarya Kota Sabang). Jurnal Ilmiah Mahasiswa Ekonomi Akuntansi, 5(2), 213-221.

Moh, F. (2019). Pengaruh Akuntabilitas, Transparansi Dan Komitmen Organisasi Terhadap Pengelolaan Dana Desa Di Kecamatan Momunu Kabupaten Buol. Bomba: Jurnal Pembangunan Daerah, 1(2), 57-64.

Sunardi, N., \& Lesmana, R. (2020). Pelaksanaan Alokasi Dana Desa Terhadap Manajemen Keuangan Desa dalam Meningkatkan Efektivitas Program Desa Sejahtera Mandiri Di Desa Cihambulu, Kec. Pabuaran, Kab. Subang. Jurnal SEKURITAS (Saham, Ekonomi, Keuangan dan Investasi), 3(3), 277-288.

Setio, S. T. I. A. S., Bungo, M., No, J. S. S., \& Jambi, K. P. P. K. B. (2019). Transparansi Penggunaan Dana Desa Dalam Rangka Meminimalisir Patologi Administrasi. Patologi Birokrasi Dalam Sebuah Monograf.

Setyawati, V. D., \& Ferdinand, D. Y. Y. (2020). Transparansi Dan Akuntabilitas Pengelolaan Dana Desa Dalam Pemaknaan Masyarakat Desa Secara
Kualitatif. JAE: Jurnal Akuntansi dan Ekonomi, 5(2), 122-127.

Nengsih, W., Adnan, F., \& Eriyanti, F. (2019). Penerapan Prinsip Transparansi Dan Akuntabilitas Dalam Pelaksanaan Pelayanan Publik Di Kelurahan Alai Parak Kopi Kota Padang. Jurnal Mahasiswa Ilmu Administrasi Publik, 1(2), 112-124.

Amalia, Z., Malikah, A., \& Mahsuni, A. W. (2020). Transparansi Dan Akuntabilitas Pengelolaan Dana Desa Yang Sesuai Dengan Pelaporan Akuntansi Sektor Publik (Studi Kasus Di Desa seKecamatan Pakis Kabupaten Malang). Jurnal Ilmiah Riset Akuntansi, 9(08). 